\title{
Evaluation of Released Potato (Solanum Tuberosum L.) Varieties in Benishangul Gumuz Region, Western Ethiopia
}

\author{
Desta Bekele $^{1 *}$ and Jamal Ebrahim ${ }^{2}$ \\ Ethiopian Institute of Agricultural Research, Assosa Agricultural Research Center, Department of Horticulture. \\ *Corresponding Authors: Desta Bekele, Ethiopian Institute of Agricultural Research, Assosa \\ Agricultural Research Center, Department of Horticulture.
}

\begin{abstract}
Potato (Solanum tuberosum L.) plays a major role in national food security, poverty alleviation and income generation. The study was designed to evaluate different potato varieties on yield and yield components of potato at Assosa, in Western Ethiopia. The treatments consisted of released potato varieties Belete, Dagim, shonkolla, Gudane, Jallane and Guassa. The treatments were laid out as a Randomized Complete Block Design with three replications. At Assosa condition Shonkola varieties was recorded highest total tuber yield among six potato varieties which gave 35.06 ton/ha whereas Dagim recorded the lowest total tuber yield $19.12 \mathrm{t} / \mathrm{ha}$. In case of Maokomo sub site the highest total tuber yield (24.23 t/ha) was obtained from Belete variety while the lowest total tuber yield $(9.64 \mathrm{t} / \mathrm{ha})$ was recorded by Guassa variety. So, we tentatively recommended that shonkola variety was best for Assosa area followed by Belete variety. In case of Maokomo we recommended that Belete variety was best for Maokomo area followed by Dagim variety.
\end{abstract}

Key words: Potato, Varieties, Evaluation and Tuber

\section{INTRODUCTION}

Potato (Solanum tuberosum L.) belongs to the Solanaceae family. It is the fourth most important crop after rice, wheat, and maize, and has historically contributed to food and nutrition security in the world (FAO, 2015). Potato (Solanum tuberosum L.) is a leading food and cash crop in Ethiopia, especially in the highlands of the country. It has the potential to supply a cheap and quality food within relatively short period of time. The crop has the greatest potential to produce greater amount of yield per unit land than cereals and is only exceeded nutritionally by fish, sweet potato and rice (EARO, 2000). It is considered to be the source of proteins, vitamin, minerals, energy and amino acids (Pual, 1992). For this reasons, envisaged that potato has a promising potential to make a very significant nutritional and economic benefits of both rural and urban communities of Ethiopia.

On the other hand, ensuring food security is one of the greatest challenges facing the world community including Ethiopia (FAO, 2001). Sustainable food production to feed the ever increasing human population is a critical issue today. The dual challenge of meeting human food requirements and maintaining or even improving the quality of environment is the basic objective of sustainable crop production. Therefore, to continuously generate high yielding potato verities that can be adapted to major growing areas of the region, the varietal selection activity has to be continuous. The number of farmers growing potato in Benishangul Gumuz region was approximately 3,277 in 2016 and increased to 8,359 farmers in 2017 (CSA, 2017). However, both production as well as productivity has been very low despite the existing favorable climatic conditions, edaphically factors and cheap land resources.

\section{Statement of Problem}

The regional average yield of potato, estimated at 6.5 tons Assosa zone and 2.0 tons/ha at Mao-Komo special woreda (Farming System Survey in BGRS, 2006) when compared to national average yield, 13.7 tons per hectare (CSA, 2017). This low yield is attributed mainly due to the potato varieties available at the hands of the farmers in the region are poor yielder and susceptible to diseases particularly, late blight (Assosa Research Strategy Document, 2005). Hence, lack of high yielding potato varieties, which are tolerant/resistant to major diseases and insect pests, is becoming the major problem prevailing in the region. 


\section{Significance/ Motivation of the study/}

Potato production in Benishangul Gumuz is low as compared to national potato production in ton per ha because the farmers uses local potato varieties. The significance of this study is to increase potato production using improved potato variety (ies) in Benishangul Gumuz Region.

\section{Scope and limitation of the study}

Some varieties were showed the highest yield at Maokomo as compared to Assosa area due to geographical difference. At Assosa area diseases were occurred on some varieties as compared to Maokomo area. Late blight limited potato yield if not planted at proper time. It is important to plant early June at Assosa and Maokomo condition.

\section{Objective}

To evaluate adaptable and high yielding with good quality potato varieties for users

\section{Materials ANd Methods}

The experiment was conducted at Assosa Agricultural Research Center in two locations, Assosa on station and Tongo and during 2017/2018 cropping seasons. The center is located at latitude of $10^{\circ} 02^{\prime}$ $\mathrm{N}$ and longitude of $34^{0} 34^{\prime} \mathrm{E}$ in western Ethiopia. It is characterized by altitude ranging from $1553 \mathrm{~m}$ a.s.l. and mean annual rainfall of $1275 \mathrm{~mm}$. The rainy season extends from April to October and maximum rain is received in the months of June to August. It has a warm humid climate with mean maximum and minimum temperatures are $32.0^{\circ} \mathrm{C}$ and $17.0^{\circ} \mathrm{C}$, respectively. The soil of the area is characteristically reddish, brown, Nitosol, which is slightly acidic, pH of 5.5 (EARO, 2004).

Mao-Komo Special Wereda is one of the 20 Weredas found in Benishangul-Gumuz National Regional State, its capital, Tongo, located $116 \mathrm{~km}$ away from Asossa town. It is bordered by Oromia Region in the east, Sudan in the west, Asossa Zone in the north and Gambela Region in the south. The altitude of the area ranges from $950-1800$ m.a.s.l whose $15 \%$ and $85 \%$ is categorized as mid altitude and lowland, respectively. The temperature of the area ranges from $23-35^{\circ} \mathrm{C}$.

The experimental design was RCBD with three replications. Six recently released potato varieties, Dagim(v1), Shonkola (v2), Guasa (CIP-384321-9(v3)), Belete (CIP-393371-58(v4)), Jalane(v5), and Gudane(v6) were tested as a treatments. The total numbers of plots were 18 and each plot had a size of $9 \mathrm{~m}^{2}$ areas with five rows and 10 plants per row with a total population of 40 plants per plot at spacing of $0.75 \mathrm{~m}$ and $0.30 \mathrm{~m}$ between rows and plants, respectively. All crop cultural practices were followed as per the recommend packages. Data were collected for plant height $(\mathrm{cm})$, main stem number per hill, average tuber weight per hill, marketable tuber yield, unmarketable tuber yield and total tuber yield.

\section{Data Analysis}

Data were analyzed using analysis of variance procedures on the appropriate statistical analysis software (SAS, 2010) version 9.0. Whenever the treatment differences show significance, mean differences was tested by LSD at $5 \%$ level of significance

\section{RESULTS AND DISCUSSION}

\section{Growth Performance and Yield Components}

Plant height and number of main stems per hole: The results showed that no significance difference $(\mathrm{P}>0.05)$ among varieties in terms of plant height and number of main stems both at Assosa and Maokomo.

Average of fresh weight per plant: the result revealed that not significantly influenced by different varieties at Assosa area, but average fresh fruit per plant was highly significantly influenced by different potato varieties at Maokomo site. The highest average fresh tuber per plant (696.80 g) was observed from Belete variety.

Average of dry weight per plant: the result showed that average of dry weight per plant was not significantly affected by different varieties at Assosa, but it was highly significantly $(\mathrm{P}<0.01)$ affected by different varieties at Maokomo. 
Total tuber number per plant: the result showed that not significantly $(\mathrm{P}>0.05)$ affected by different varieties at Assosa, but it was highly significantly affected $(\mathrm{P}<0.01)$ by different varieties at Maokomo. The highest total tuber number per plant at Maokomo was observed from Guassa and Jalane varieties (7.87) whereas the lowest total tuber number per plant (5.6) Dagim variety.

Table1. Mean of growth performance potato varieties at Assosa and Maokomo in 2017/18

\begin{tabular}{|c|c|c|c|c|c|c|c|c|c|c|}
\hline \multirow[t]{2}{*}{ Trts } & \multicolumn{2}{|r|}{$\mathrm{PH}(\mathrm{cm})$} & \multicolumn{2}{|c|}{ NSPH } & \multicolumn{2}{|c|}{$\operatorname{AFWPP}(\mathrm{g})$} & \multicolumn{2}{|c|}{$\operatorname{ADWPP}(\mathrm{g})$} & \multicolumn{2}{|c|}{ TNPP } \\
\hline & $\begin{array}{l}\text { Assos } \\
\mathrm{a}\end{array}$ & $\begin{array}{c}\text { Maoko } \\
\text { mo }\end{array}$ & $\begin{array}{c}\text { Assos } \\
\text { a }\end{array}$ & $\begin{array}{l}\text { Maoko } \\
\text { mo }\end{array}$ & $\begin{array}{l}\text { Assos } \\
\mathrm{a}\end{array}$ & $\begin{array}{l}\text { Maoko } \\
\text { mo }\end{array}$ & $\begin{array}{l}\text { Assos } \\
\text { a }\end{array}$ & $\begin{array}{l}\text { Maoko } \\
\text { mo }\end{array}$ & $\begin{array}{l}\text { Assos } \\
\mathrm{a}\end{array}$ & $\begin{array}{l}\text { Maoko } \\
\text { mo }\end{array}$ \\
\hline Dagim & 52.93 & 55.45 & 3.43 & 3.73 & 337.9 & $493.20 b$ & 88.03 & $116.33 b$ & 8.20 & 5.60 \\
\hline $\begin{array}{l}\text { Shonko } \\
\text { la }\end{array}$ & 61.53 & 49.25 & 3.47 & 4.1 & 476.6 & $\begin{array}{l}400.10 b \\
\mathrm{c}\end{array}$ & $\begin{array}{c}107.2 \\
4 \\
\end{array}$ & $73.90 \mathrm{c}$ & 9.33 & 6.20 \\
\hline Guasa & 61.87 & 51.23 & 4.53 & 3.6 & 469.3 & $378.80 \mathrm{c}$ & $\begin{array}{c}146.9 \\
5 \\
\end{array}$ & $80.33 c$ & 12.07 & 7.87 \\
\hline Belete & 62.67 & 59.67 & 3.33 & 4.27 & 442.1 & $696.80 \mathrm{a}$ & $\begin{array}{c}134.1 \\
6 \\
\end{array}$ & $181.73 \mathrm{a}$ & 6.40 & 6.27 \\
\hline Jalane & 56.40 & 40.53 & 3.00 & 2.8 & 605.3 & $368.20 \mathrm{c}$ & $\begin{array}{c}131.9 \\
8 \\
\end{array}$ & $81.79 \mathrm{c}$ & 11.33 & 7.87 \\
\hline Gudane & 50.40 & 47.83 & 2.87 & 3.27 & 384.4 & $\begin{array}{l}433.40 \mathrm{c} \\
\mathrm{b}\end{array}$ & 84.19 & $110.51 b$ & 8.27 & 7.4 \\
\hline $\mathrm{CV}$ & 9.63 & 11.46 & 21.67 & 17.15 & 39.47 & 13.22 & 38.24 & 12.61 & 23.98 & 10.32 \\
\hline LSD & 10.09 & & & & $\begin{array}{c}324.9 \\
9\end{array}$ & 111.08 & 80.29 & 24.64 & 4.04 & 1.29 \\
\hline $\begin{array}{l}\text { Sign } \\
\text { Level }\end{array}$ & Ns & Ns & Ns & Ns & Ns & $* *$ & Ns & $* *$ & Ns & $* *$ \\
\hline
\end{tabular}

Ns $=$ Non significance, $* *=$ highly significant, $*=$ significant, $L S D=$ Least Significant Difference, $C V=$ Coefficient of Variation, $P H=$ plant Height, NSPH= Number of Stem per hole, AFWPP=Average Fresh Weight $P$ er plant, $A D W P P=$ Average dry weight per plant, $T N P P=$ Total number of tuber per plant .

\section{Yield Attribute Parameters}

Marketable tuber yield: highly significantly $(\mathrm{P}<0.01)$ affected by different potato varieties both at Assosa and Maokomo. The highest marketable tuber yield (20.49 t/ha) was obtained from Shonkolla at Assosa whereas the lowest marketable tuber yield (11.09 t/ha) was recorded from Gudane variety at Assosa. The highest marketable tuber yield observed from Belete variety $(23.86 \mathrm{t} / \mathrm{ha})$ at Maokomo whereas the lowest marketable tuber yield $(8.08 \mathrm{t} / \mathrm{ha})$ at Maokomo was recorded from Guassa variety. This variation might be due to inherit potential of varieties. These results were in line with other researchers who reported that marketable tuber yield was significantly varied by variety (Elfinesh, 2008; Kumar et al., 2007).

Unmarketable tuber yield:- the results showed that no significant difference $(\mathrm{P}>0.05)$ among varieties at Assosa while it was significantly $(\mathrm{P}<0.05)$ affected by varieties at Maokomo.

Total tuber number per plot: the result revealed that there was significance difference $(\mathrm{P}>0.05)$ among varieties at Assosa whereas total tuber number per plot was highly significantly $(\mathrm{P}<0.01)$ affected by varieties at Maokomo.

\section{Total tuber yield per ha}

The results showed that total tuber yield was significantly $(\mathrm{P}<0.05)$ affected by varieties at Assosa whereas it was highly significantly $(\mathrm{P}<0.01)$ affected by different varieties at Maokomo. It might be due to inherit potential of varieties. At Assosa conditions the highest total tuber yield was recorded from the Shonkolla (35.06 ton/ha) followed by Belete (29.69 ton/ha). In case of Maokomo condition the highest tuber yield of potato was observed from Belete variety ( 24.23 ton/ha) followed by Dagim variety (21.99 ton/ha). This variation might be due to inherit potential of varieties. This results were in line with other researchers who reported that total tuber yield was significantly varied by variety (Elfinesh, 2008; Kumar et al., 2007). 
Evaluation of Released Potato (Solanum Tuberosum L.) Varieties in Benishangul Gumuz Region, Western Ethiopia

Table2. Mean of yield parameters of potato at Assosa and Maokomo in 2017/18.

\begin{tabular}{|l|l|l|l|l|l|l|l|c|}
\hline \multirow{2}{*}{ Trts } & \multicolumn{2}{|c|}{ MYLD (kg/plot) } & \multicolumn{2}{c|}{ UNMYLD (kg/plot) } & \multicolumn{2}{c|}{ TTN per plot } & \multicolumn{2}{c|}{ TTY (t/ha) } \\
\cline { 2 - 10 } & Assosa & Maokomo & Assosa & Maokomo & Assosa & Maokomo & Assosa & Maokomo \\
\hline Dagim & $11.52 \mathrm{c}$ & $21.48 \mathrm{ab}$ & 1.39 & $0.82 \mathrm{~b}$ & 133.67 & $122.00 \mathrm{~b}$ & $19.12 \mathrm{c}$ & $21.99 \mathrm{ab}$ \\
\hline Shonkola & $20.49 \mathrm{a}$ & $15.37 \mathrm{bc}$ & 3.10 & $1.82 \mathrm{a}$ & 198 & $179.00 \mathrm{a}$ & $35.06 \mathrm{a}$ & $17.19 \mathrm{bc}$ \\
\hline Guasa & $15.2 \mathrm{bc}$ & $8.08 \mathrm{~d}$ & 2.87 & $0.82 \mathrm{~b}$ & 156.33 & $77.33 \mathrm{c}$ & $26.78 \mathrm{bc}$ & $9.64 \mathrm{~d}$ \\
\hline Belete & $18.58 \mathrm{ab}$ & $23.86 \mathrm{a}$ & 1.46 & $0.37 \mathrm{~b}$ & 106 & $96.00 \mathrm{cb}$ & $29.69 \mathrm{ab}$ & $24.23 \mathrm{a}$ \\
\hline Jalane & $12.52 \mathrm{c}$ & $10.94 \mathrm{~cd}$ & 2.34 & $0.97 \mathrm{~b}$ & 122 & $115.00 \mathrm{cb}$ & $22.01 \mathrm{bc}$ & $11.91 \mathrm{~cd}$ \\
\hline Gudane & $11.09 \mathrm{c}$ & $14.38 \mathrm{~cd}$ & 2.33 & $0.84 \mathrm{~b}$ & 148.33 & $117.33 \mathrm{~b}$ & $19.89 \mathrm{c}$ & $15.23 \mathrm{~cd}$ \\
\hline CV & 15.68 & 21.25 & 47.46 & 40.84 & 20.18 & 17.70 & 17.10 & 20.07 \\
\hline LSD & 4.25 & 6.61 & 1.95 & 0.66 & 52.88 & 37.93 & 12.82 & 14.63 \\
\hline Sign Lev & $* *$ & $* *$ & NS & $*$ & NS & $* *$ & & $*$ \\
\hline
\end{tabular}

Ns $=$ Non significance, $* *=$ highly significant, $*=$ significant, LSD $=$ Least Significant Difference, CV Coefficient of Variation. MTW=Mean tuber weight, MYLD= Marketable tuber Yield, UNMYLD=Unmarketable tuber yield, TTN= Total tuber number per plot, TYPH= Total tuber yield per ha.

\section{Tuber Size Distribution}

Mean tuber weight $(\mathbf{g})$ : mean tuber weight was not significantly $(\mathrm{P}>0.05)$ affected by varieties at Assosa, it was highly significantly $(\mathrm{P}<0.01)$ affected by varieties at Maokomo. The highest mean tuber weight $(110.88 \mathrm{~g})$ was observed from Belete variety at Maokomo whereas the lowest mean tuber weight $(43.20 \mathrm{~g})$ was recorded from Shonkolla variety. The variation may be attributed to an inherit potential of the genotypes. Patel et al. (2008) and Kumar et al. (2007) also reported that maximum yield of small size tubers may be due to higher number of tubers as well as varietal character and adaptability or establishment effect of other growth attributes.

Number of small tuber size per plot: it was not significantly $(\mathrm{P}>0.05)$ affected by varieties at Assosa whereas it was highly significantly $(\mathrm{P}<0.01)$ affected by varieties at Maokomo.

Number of medium tuber size per plot: it was not significantly $(\mathrm{P}>0.05)$ affected by varieties both at Assosa and Maokomo areas.

Number of large tuber size per plot: Large tuber size of potato in number was not significantly $(\mathrm{P}>0.05)$ affected by varieties at Assosa whereas it was highly significantly $(\mathrm{P}<0.01)$ affected by varieties at Maokomo.

Table3. Mean of number of size distribution per plot and mean tuber weight of potato at Assosa and Maokomo site in 2017/18 cropping season.

\begin{tabular}{|l|l|l|l|l|l|l|l|l|}
\hline \multirow{2}{*}{ Trts } & \multicolumn{2}{|c|}{ MTW (g) } & \multicolumn{2}{c|}{ STSD } & \multicolumn{2}{c|}{ MTSD } & \multicolumn{2}{c|}{ LTSD } \\
\cline { 2 - 10 } & Assosa & Maokomo & Assosa & Maokomo & Assosa & Maokomo & Assosa & Maokomo \\
\hline & & & & & & & & \\
Dagim & 41.23 & $88.317 \mathrm{~b}$ & 50.33 & $23.33 \mathrm{~d}$ & 51.67 & 55 & 24.33 & $44.000 \mathrm{a}$ \\
\hline Shonkola & 54.46 & $43.203 \mathrm{~d}$ & 92 & $90.00 \mathrm{a}$ & 55.33 & 66 & 49.67 & $23.500 \mathrm{cb}$ \\
\hline Guasa & 39.12 & $48.147 \mathrm{dc}$ & 99.33 & $35.67 \mathrm{~cd}$ & 57.67 & 31 & 34.67 & $10.333 \mathrm{~d}$ \\
\hline Belete & 69.69 & $110.880 \mathrm{a}$ & 22 & $34.33 \mathrm{~cd}$ & 38.67 & 38.67 & 47.67 & $32.333 \mathrm{~b}$ \\
\hline Jalane & 52.99 & $46.687 \mathrm{dc}$ & 64.33 & $64.00 \mathrm{~b}$ & 33.33 & 27 & 17.67 & $16.667 \mathrm{~cd}$ \\
\hline Gudane & 45.42 & $58.490 \mathrm{c}$ & 74.67 & $49.33 \mathrm{cb}$ & 51 & 37.33 & 16.33 & $19.667 \mathrm{c}$ \\
\hline CV & 27.73 & 10.89 & 38.79 & 26.49 & 37.18 & 42.04 & 50.39 & 20.89 \\
\hline LSD & 25.47 & 13.08 & 47.37 & 23.83 & 32.43 & 33.57 & 29.08 & 9.28 \\
\hline $\begin{array}{l}\text { Sign } \\
\text { Level }\end{array}$ & Ns & $* *$ & Ns & $* *$ & Ns & Ns & Ns & $* *$ \\
\hline
\end{tabular}

$* *$ = highly significantly difference, $N$ s = Non significant, MTW=Mean tuber weight, STSD= Small tuber size distribution, MTSD= Medium tuber size distribution, LTSD= Large tuber size distribution.LSD= Least Significance difference, $C V=$ Coefficient of Variation.

\section{CONCLUSION AND RECOMMENDATION}

Six recently released potato varieties are Dagim, Shonkola, Guasa (CIP-384321-9), Belete (CIP393371-58), Jalane, and Gudane were tested as a treatments in 2017/18 cropping season both at Assosa and Maokomo. Among those Belete, Shonkola and Dagim were the best performing varieties. 
From those, two varieties Shonkola and Belete were best performed at Assosa whereas Belete and Dagim varieties were well performed at Mao-Komo sub site. This showed that Belete variety was widely adaptable on both locations while Shonkola was well performed at Assosa whereas Dagim was well performed at Mao-komo area. We tentatively recommended that Shonkola variety was best for Assosa area followed by Belete variety whereas Belete variety was well performed in case of Maokomo area followed by Dagim variety.

\section{REFERENCES}

[1] CSA (Central Statistical Agency). 2017. Agricultural sample survey 2016/2017. Vol. I. Report on farm management practices (private peasant holdings, meher season). Statistical Bulletin 584, Central Statistical Agency. Addis Ababa, Ethiopia

[2] EARO (Ethiopian Agricultural Research Organization), 2004. Research Strategy Document for Assosa Agricultural Research Center, Benishangul Gumuz National Regional State. Ethiopian Agricultural Research Organization, Addis Ababa, Ethiopia. Pp 1-6.

[3] EIAR, 2005. Assosa Agricultural Research Center Strategic Plan, 2006-2008

[4] EIAR, 2000. Horticultural Research Strategic Crop Research Directorate, July 2000.

[5] EIAR, 2006. Results of Farming System Survey in Benishangul Gumuz Regional State, Assosa

[6] Elfinesh F. (2008). Processing quality of improved Potato (Solanum tuberosum L.) varieties as influenced by growing environment, genotype and blanching. An M. Sc. Thesis submitted to the school of graduate studies of Haramaya University

[7] FAO, 2001. Agricultural Investment and Productivity in Developing Countries. Economic and Social Development Paper 148, Food and Agricultural Organization of the United Nation. Rome, Italy.

[8] FAOSTAT.2015. Data base of agricultural production. Food and Agriculture Organization, Rome, Italy.

[9] Kumar S., Khade H.D., Dhokane V.S., Bethere A.G., and Sharma A., (2007). Irradiation in Combination With Higher Storage Temperatures Maintains Chip-Making Quality of Potato. J. Food sci.72.

[10] Patel C.K., Patel P.T. and Chaudhari S.M., (2008). Effect of physiological age and seed size on seed production of potato in North Gujarat, 35: 85-87.

[11] Paul, H., 1992.The Potato Crop, $2^{\text {nd }}$ ed. Chapman and Hall, 2-6 Boundary Row, London

[12] SAS Institute, 2010. SAS/ATAT User Guide: Vers. $74^{\text {th }}$ ed. SAS Inst, Cary, N.C.

Citation: Desta Bekele \& Jamal Ebrahim, “ Evaluation of Released Potato (Solanum Tuberosum L.) Varieties in Benishangul Gumuz Region, Western Ethiopia” International Journal of Research Studies in Agricultural Sciences (IJRSAS), 2020; 6(11), pp. 10-14, https://doi.org/10.20431/2454-6224.0611003

Copyright: (C) 2020 Authors. This is an open-access article distributed under the terms of the Creative Commons Attribution License, which permits unrestricted use, distribution, and reproduction in any medium, provided the original author and source are credited. 